4. Жердєва I.C., Рашидова С.С. Методика формування іміджу викладача вищої школи. Духовність особистості: методологія, теорія і практика. 2016. № 4 (73). С.48-61.

5. Найбільше мають лісівники, значно менше - вчителі та медики: в кого та які зарплати на Рівненщині. URL: https://rivne.media/news/ naybilshe-mayut-lisivniki-znachno-menshe---vchiteli-ta-mediki-v-koho-tayaki-zarplati-na-rivnenshchini

DOI https://doi.org/10.30525/978-9934-26-173-2-33

\title{
ІННОВАЦІЙНА ДІЯЛЬНІСТЬ ПЕДАГОГА ЯК СКЛАДОВА СУЧАСНОГО ОСВІТНЬОГО ПРОСТОРУ: ФІЛОСОФСЬКО-ОСВІТНІЙ АСПЕКТ
}

\author{
Славінська О. М. \\ аспірантка \\ КЗВО «Одеська академія неперервної освіти Одеської обласної ради» \\ м. Одеса, Україна
}

Для XXI століття характерною є доволі-таки стрімка та глибинна модернізація всіх сторін суспільного життя. Зауважимо, що надзвичайно швидко змінюються тенденції щодо утворення єдиного світового, принаймні європейського, економічного та освітнього простору 3 певного аспекту. А от $з$ іншого аспекту, на рівні держави зростають ті чинники, основу яких складають такі культурно-національні особливості, як духовність, ментальність, історична спадщина та освіченість народу. Нині, розвинені суспільства мають на меті реалізувати та організувати навчально-виховний процес таким чином, аби левова частка їхньої спільноти протягом певного часу отримала статус всебічно розвинених особистостей, які б зуміли досягти високого рівня розвитку.

Саме тому трансформаційні процеси та неперервна інформаційна змінність зумовлюють включення людини в складну систему суспільних взаємовідносин, потребують від неї здатності та вміння реалізації нестандартних і швидких рішень. Виходячи із цього, у підходах до навчально-виховної діяльності, вагома увага має приділятися питанням подолання консерватизму, а також існуючих стереотипів педагогічної праці та процесу мислення як в учасників навчання і виховання, так і у освітян. 
Шляхи підвищення професійної підготовки вчителя сучасної школи, який вміло поєднує теоретичну та практичну частини, має високий рівень своєї обізнаності - часто розглядається у науковій літературі. Адже складовою його професіоналізму і компетентності являється саме вміння застосовувати новітні освітні ресурси на практиці. Існує нова окрема галузь педагогіки, яка досліджує способи їх досягнення, а саме педагогічна інноватика. Її діяльність спрямована першочергово на те, щоб забезпечети навчально-виховний процес у відповідності до вимог сучасного суспільства $[6,8]$.

Над розробкою більшості напрямів досліджень освітньої інноватики працюють вітчизняні та зарубіжні науковці. Аналізують та вивчають різноманітні новітні моделі змісту педагогічної освіти М. Євтух, О. Дубасенюк, І. Зязюн, та інші. Зокрема, досліджують сутність вивчення інновацій I. Підласий, В. Паламарчук, М. Ярмаченко тощо. Розробкою та впровадженням системи управління інноваційними освітніми процесами займаються Л. Ващенко, Л. Даниленко, О. Мармаза $[2,3]$.

Інноваційне суспільство виражає потребу в особистості, яка здатна втілити в життя компетентнісний підхід та розвивати в учнів якості, які дозволять їм системно мислити, створювати й реалізовувати нові ідеї, самостійно набувати нових професійно важливих компетентностей, приймати рішення, бути відповідальними за результати своєї діяльності та адаптуватися до швидкозмінних соціально-економічних умов. Цей процес починається з початкової школи, для якої XXI століття стало визначальним, через впровадження нових ідей, закладених у концепції Нової української школи, яка має на меті створення всеосяжної особистості нового покоління, впровадження в освітній процес педагогічних інновацій. Все це вимагає від учителя відкритості до змін, постійного саморозвитку і самовдосконалення, і виводить на новий рівень [10].

Теоретико-методологічні засади вивчення феномену інноваційної компетентності педагога визначені в працях I. Гавриш, I. Дичківської, В. Докучаєвої, О. Ігнатович, Н. Клокар, Є. Макагон, Л. Петриненко, О. Подимової, В. Позднякова, В. Сластьоніна, О. Шафран, Г. Хмельницького, А. Хуторського.

I. Дичківська пропонує розрізняти поняття «новація» («новий засіб») як певний засіб (нові ідеї, методи, методики, технології, програми тощо) та «інновації», яке ширше за змістом, оскільки означає процес, предметом якого $є$ новації [4].

Так, В. Уруський виділяе готовність педагога до інноваційної практики, яка виражається через уміння та навички виокремити більш 
дієві способи та прийоми впровадження нововведень, вміле володіння використаними методиками і технологіями [11].

Поняття «інновація» має багато трактувань і по-різному розкривається у філософії, психології, педагогіці, економіці та інших соціальних науках. Вперше це поняття ввів видатний австрійський та американський економіст, політолог, соціолог Й. А. Шумпетер в монографії «The Theory of Economic Development» (1934 p.), науково обгрунтувавши зміст даного поняття, як «зміни», а головною функцією інноваційної діяльності він назвав «функцію управління змінами», це дуже загальний i широкий погляд на інновації, згідно 3 ним під інноваціями можна розуміти «внесення в різноманітні види людської діяльності нових елементів (способів), що підвищують результативність цієї діяльності» [5].

У філософії «інновацією» називають складний процес, результатом якого $є$ певні новаторства, що мають не просто соціальну значимість, а задовольняють певну суспільну потребу. Інновації, з одного боку, $є$ способом вирішення соціальних проблем, але, з протилежного боку, джерелом нестабільності, складно передбачуваних наслідків і ризиків, що призводить до зростання швидкості змін, стресів і залежностей, інформаційної втоми, адаптаційних зривів [1].

О. Чумак, досліджуючи філософський аспект інновації, тлумачить це поняття як можливість зуміти подолати бар'єр складного проблемного філософського мислення, вміти бачити та виявляти проблеми, шляхи, засоби їх вирішення, цілеспрямоване впровадження в існуючу практику того чи іншого нововведення, завдяки якому відбуваються позитивні зрушення і досягається необхідний ефект [12].

У педагогіці інновація набуває іншого, своєрідного трактування, відповідно до досліджуваної проблеми - освіти людини. Умови, в яких відбувається освітній процес, важливі, але не вони є метою інновацій, про це важливо пам'ятати, щоб чітко розуміти, що планується і відбувається в освіті. Під «педагогічними інноваціями» розуміються нововведення в педагогічній системі, спрямовані на поліпшення перебігу і результатів навчально-виховного процесу [9].

Що стосується поняття «інноваційна діяльність», то його необхідно розглядати в просторі певної практики. 3 погляду конкретного суб’єкта цієї практики інноваційною можна вважати будь-яку діяльність, що приводить до істотних змін іiі результату, порівняно 3 існуючою традицією. У педагогічній науці інноваційна діяльність розуміється як цілеспрямована педагогічна діяльність, заснована на осмисленні (рефлексії) свого власного практичного педагогічного досвіду за допомогою порівняння і вивчення, зміни і розвитку освітнього процесу 
3 метою досягнення більш високих результатів, отримання нового знання, якісно іншої педагогічної практики [7].

Зважаючи на вищезазначене, зауважимо, що можна виокремити певні компоненти пов'язані із готовністю педагога до інноваційної діяльності: нині це є актуальна проблема сучасності, науки та практики в цілому, вирішення якої покладено на систему освіти зокрема. Так як інновації в широкому філософському трактуванні $\epsilon$ необхідною складовою сучасної системи освіти. Зазначимо, що в більш прикладному, педагогічному значенні, інновації на кожному етапі освіти мають свою специфіку, яка відображається в особливостях реалізації і змісту нововведення.

Інноваційний розвиток - це передусім вдосконалення чи оновлення освітньої практики, яке реалізовується через створення, поширення та засвоєння нових ефективних засобів та прийомів досягнення поставлених цілей освіти. А тому прагнення до інноваційної діяльності $\epsilon$ інтегральною якістю особистості, характерною якій $\epsilon$ наявність сформованості мотиваційно-орієнтаційного, змістовно-операційного i оцінно-рефлексивного компонентів у їх єдності, що виражаються в прагненні до інноваційного процесу на професійному рівні.

\section{Література:}

1. Воробьева (Пригода) Н. С. Философская интерпретация сущности инноваций Изв. Сарат. ун-та. Нов. сер. Сер. Философия. Психология. Педагогика. 2018. Т. 18, вып. 1. - С. 11-15.

2. Гальченко В. Комп'ютерні технології в освіті: реалії та перспективи. Інформатика та інформ. технології. 2012. № 3. - С. 17-20.

3. Грицай Н. Б. Теорія і практика методичної підготовки майбутніх учителів: монографія. Рівне: О. Зень, 2016. - С. 440.

4. Дичківська I. М. Інноваційні педагогічні технології: підручник 3-тє видання, виправлене («Академвидав») / I. М. Дичківська. - Київ, 2015. - С. 304.

5. Ефименко Т. И. Научное творчество И. А. Шумпетера как инновационная деятельность и современность / Т. И. Ефименко, П. М. Леоненко // Фінанси України. - 2013. - № 12. - С. 7-20.

6. Коренева I. М. Компетентності вчителя: погляд крізь освіту для сталого розвитку. Науковий часопис НПУ імені М. П. Драгоманова. 2018. № 62. - C. 108-113.

7. Макогон К. Діагностика готовності педагогів до пошукової діяльності (пед.інновації) / Рідна школа. - 2002. - №1 . - С. 27-29. 
8. Макогоненко М. Використання інформаційних технологій навчання в практиці роботи вчителя. Збірник наукових праць. Частина 4. 2012. - С. 230-236.

9. Полонский В. М. Инновации в образовании (методологический анализ) // Инновации в образовании. 2007. №3. - С. 68.

10. Сорочан Т. М. Професійний розвиток педагога Нової української школи в умовах формальної і неформальної освіти: збірник спецкурсів / Авторський колектив. Київ: Агроосвіта, 2018.

11. Уруський В. І. Формування готовності вчителів до інноваційної діяльності: Методичний посібник. - Тернопіль: ТОКІППО. 2005. - С. 96.

12. Чумак О. В. Інноваційна діяльність як чинник розвитку суспільства в умовах глобалізації: дис. на здобуття наукового ступеня канд. філософ. наук: 09.00.03. Запоріжжя, 2015. - С. 196.

DOI https://doi.org/10.30525/978-9934-26-173-2-34

\section{ЗАПРОВАДЖЕННЯ ІНТЕРАКТИВНИХ ЗАСОБІВ У ВИКЛАДАННІ КЛІНІЧНИХ ДИСЦИПЛІН В СУЧАСНИХ УМОВАХ ПАНДЕМІЇ COVID-19}

\section{Харченко Ю. П.}

доктор медичних наук, професор, завідувач кафедри дитячих інфекційних хвороб Одеський начіональний медичний університет

Юрченко І. В. кандидат медичних наук, доцент кафедри дитячих інфекційних хвороб Одеський національний медичний університет

Зарецька А. В.

асистент кафедри дитячих інфекиійних хвороб, доктор філософії Одеський начіональний медичний університет м. Одеса, Украӥна

В умовах постійних спалахів інфекційних хвороб, завдяки розвиненій транспортній галузі, з кожним роком все більше підвищується попит на лікарів компетентних 3 діагностики та лікування інфекційних хвороб. 